\title{
HARMFUL EFFECTS AND MONITORING OF NOISE
}

\author{
Mladen D. Nikolić, dipl. ing. College for chemical-technological school, Kruševac, Serbia \\ mladennikolic2603@yahoo.com
}

PhD Dragan M. Nikolić, prof. College for chemical-technological school, Kruševac, Serbia dragannikolic60@yahoo.com

MSc Fortuna Dragutin, College for chemical-technological school, Kruševac, Serbia

\begin{abstract}
High noise levels can contribute to different health problems. This paper shows the results of monitoring of noise in urban enviroment. Fonometer has been used for measuring. The measurements were made on five different places. The measurements were made at day, dusk and at night. Five measurements were made at each site. The results shows that the noise level at certain sites is higher than allowed (by 20 $\mathrm{dB}$ ). In order to minimize noise level some counter measures has to be done.
\end{abstract}

Key words: noise, fonometer, monitoring, traffic, measuring sites.

\section{Introduction}

Noise is every unwanted sound. that means that every sound effect (roistering, murmur...) that disrupts work or reposing can be represented as noise. To make a sound called noise it needs to be lound enough, different that other sounds in that moment.

In basics, we can define two types of noise, by its source: noise of natural sources, and manmade noise.

Noise in urban enviroment can be partitioned on noise in working enviroment and noise in living enviroment.

Effects of noise can be partitioned on auditory, extraauditory, and psychogenic. By frequency characteristics it can be partitioned on: the effects of audible noise spectrum, infra sound, ultrasound and vibration effects.

It should be noted that man does not permit either absolute silence, what is the example of a completely isolated chambers. Then the noise of the body, such as: heart rate, respiration, digestion and blood flow becomes very loud and unpleasant.

When background noise of over $60 \mathrm{~dB}$ and $80 \mathrm{~dB}$ above particular note is the relatively rapid increase in symptoms of sympathetic tone, that the increased intensity becomes very pronounced and occur in a short time after the beginning of exposure. The aforementioned effect is manifested in blood pressure increase, decrease stroke volume of the heart and reduces peripheral blood circulation. Changes in breathing, changes in bowel movements, changing the function of the central nervous system and overall metabolism. And endocrine disturbances occur, expressed in particular in release of adrenal glands, pancreas then, and pituitary. All this is accompanied by fatigue, irritability, insomnia and vegetative disturbances of various degrees.

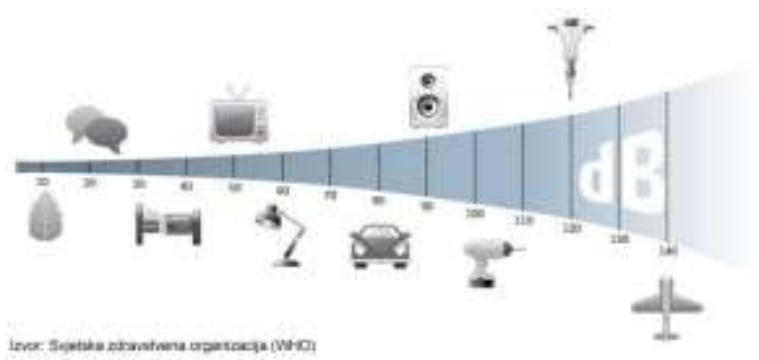

Fig.1. Noise levels from various sources 1

Noise sources can vary, some sources which can create a certain level of noise is shown in Figure (1). For communal environment of particular importance is the noise generated by the internal combustion engine and of traffic.

\section{Aim and methods}

The aim of this study was to measure the value of noise in the urban environment. The measured values are compared to the allowable noise levels.

Noise measurement was conducted in the city of Krusevac. Noise measurement was performed on five measuring points: Fountain Square, the United Nations Settlement, 
Bagdala Park, Pools - Sports Centre Lazaricadirection to Kraljevo, and the results are compared to the allowable noise levels.

To measure the noise level Phonometer was used. Dynamic range of sound level meters from $26 \mathrm{~dB}$ to $140 \mathrm{~dB}$, thus providing noise monitoring on the widest range.

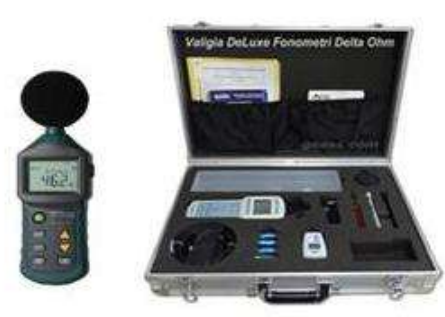

FIGURE 2. PHONOMETERS 1

Terms noise measurements are shown in Table. (1)

\begin{tabular}{|c|c|c|c|c|}
\hline \multicolumn{2}{|c|}{$\begin{array}{c}\text { Day period } \\
\text { from 06:00 am to 06:00 pm }\end{array}$} & \multicolumn{2}{|c|}{$\begin{array}{c}\text { Dusk period 06:00pm to } \\
10: 00 \mathrm{pm}\end{array}$} & $\begin{array}{l}\text { Night period } \\
\text { 10:00 pm to - } \\
06: 00 \mathrm{am}\end{array}$ \\
\hline $\begin{array}{c}\text { I } \\
\text { Measurement }\end{array}$ & $\begin{array}{c}\text { II } \\
\text { Measurement }\end{array}$ & $\begin{array}{c}\text { III } \\
\text { Measurement }\end{array}$ & $\begin{array}{c}\text { IV } \\
\text { Measurement } \\
\end{array}$ & V Measurement \\
\hline 09-11:00 am & 12:00 am 02:00 pm & $\begin{array}{l}\text { 08:00 pm } \\
10: 00 \mathrm{pm}\end{array}$ & $\begin{array}{c}10: 00 \mathrm{pm} \\
00: 00\end{array}$ & $\begin{array}{c}00: 00 \\
06: 00 \mathrm{am}\end{array}$ \\
\hline
\end{tabular}

Table 1. Terms of measurement

\section{Measuring sites}

Municipal noise measurements were made at five stations. During measurement followed by the number of vehicles that have passed since the noise is mainly caused by traffic.

1. Trg Fontana, measurements were carried out in addition to the memorial monuments and fountains surrounded by two very busy streets. In the vicinity of the building, and the noise of the traffic originates.

2. United Nations settlement,

3.Park Bagdala, the measurement was carried out in the park, which is surrounded on three sides by roads. Noise originates from traffic from neighboring areas and activities catering object.

4. Bazeni - Sports Centre, noise originates mainly from traffic. The street is lined with one-story and multistory buildings with shops for different purposes.
5. Lazarica-time in Kraljevo, the noise comes from the traffic. The street is lined with single-storey and singlestorey building with shops for different purposes.

\section{The results}

The measurement and allowed noise levels are shown in Table (2): 


\begin{tabular}{|c|c|c|c|c|c|c|c|}
\hline Measurin & & & & & & & \\
\hline $\begin{array}{c}\mathrm{g} \\
\text { site } \\
\text { (average } \\
\text { No of } \\
\text { vehicles } \\
\text { light/hev } \\
\text { y hourly ) }\end{array}$ & $\begin{array}{c}\text { I } \\
\text { Measurement } \\
\quad \text { (day })\end{array}$ & $\begin{array}{c}\text { II } \\
\text { Measureme } \\
\text { nt } \\
\text { (day) }\end{array}$ & $\begin{array}{c}\text { III } \\
\text { Measurement } \\
\text { (night) }\end{array}$ & $\begin{array}{c}\text { Allow } \\
\text { ed } \\
\text { level } \\
\text { of } \\
\text { noise }\end{array}$ & $\begin{array}{c}\text { IV } \\
\text { Measur } \\
\text { ement } \\
\text { (night) }\end{array}$ & $\begin{array}{c}\mathrm{V} \\
\text { Measur } \\
\text { ement } \\
\text { (night) }\end{array}$ & $\begin{array}{c}\text { Allowed } \\
\text { level of } \\
\text { noise }\end{array}$ \\
\hline $\begin{array}{c}\text { 1. Square } \\
\text { Fontana } \\
1052 / 36 \\
\end{array}$ & 65 & 62 & 63 & $65 \mathrm{~dB}$ & 60 & 56 & $55 \mathrm{~dB}$ \\
\hline $\begin{array}{c}2 . \\
\text { Settlemen } \\
\text { t UN } \\
64 / 10\end{array}$ & 46 & 47 & 46 & $55 \mathrm{~dB}$ & 48 & 42 & $45 \mathrm{~dB}$ \\
\hline $\begin{array}{c}\text { 3. Park } \\
\text { Bagdala } \\
48 / 6 \\
\end{array}$ & 60 & 48 & 53 & $50 \mathrm{~dB}$ & 60 & 54 & $40 \mathrm{~dB}$ \\
\hline $\begin{array}{l}\begin{array}{c}4 . \text { Pool } \\
\text { center }\end{array} \\
443 / 11 \\
\end{array}$ & 63 & 64 & 62 & $60 \mathrm{~dB}$ & 65 & 53 & $50 \mathrm{~dB}$ \\
\hline $\begin{array}{c}5 . \\
\text { Lazarica- } \\
\text { road to } \\
\text { Kraljevo } \\
562 / 42\end{array}$ & 69 & 70 & 70 & $55 \mathrm{~dB}$ & 64 & 64 & $45 \mathrm{~dB}$ \\
\hline
\end{tabular}

Table 2. The results of the noise measurements

\section{Discusion}

Measuring point no 1. Fountain Square.

Exceeding the noise level during the day was $3 \mathrm{~dB}, 2 \mathrm{~dB}$ during the evening were exceeded, and at night it was overrun by $5 \mathrm{~dB}$. During the measurements it was found that the communal noise has uncontinual flow and that largely comes from traffic. The average number of vehicles on the measuring site was easy/tough vehicles 1052/36.

Measuring point no.2 United Nations settlement .

Exceeding the noise level during the day and the evening was not until overdraft for the night was $3 \mathrm{~dB}$. During the measurements it was found that the utility uncountinued flow noise and largely comes from traffic. The average number of vehicles easy/tough vehicles 64/10 .

Measuring point No. 3. Bagdala Park.

Of exceeding the noise level during the day it was up to $7 \mathrm{~dB}$, for an evening of up to $5 \mathrm{~dB}$, while the night was exceeded by up to $20 \mathrm{~dB}$. During the measurements it was found that the noise has uncountinued character and is mainly derived from the vehicle in park and the activities of the citizens especially during the night. The average number of vehicles was an easy 48/6 heavy in one hour.

Measuring point No. 4. PoolsSport center. Exceeding the noise level during the day it is up to $2 \mathrm{~dB}$, to 5 in the evening and during the night $\mathrm{dB}$ to $15 \mathrm{~dB}$. During the measurements it was found that utility for continuous flow and noise that comes from traffic. The average number of vehicles easy/tough vehicles 443/11. 
Measuring point \# 5. Lazarica road to Kraljevo. Exceeding the noise level during the day was up to $15 \mathrm{~dB}$ during the night to $15 \mathrm{~dB}$, and at night to $19 \mathrm{~dB}$. During the measurements it was found that the utility for continuous flow noise and is mainly derived from traffic. The average number of vehicles was an easy 562/42 on a heavy vehicles per hour.

\section{Proposal measures}

-Divert heavy vehicles on the roads around the city, or the prohibition of heavy vehicle traffic through the city zone,

- Control of noise emitted by motor vehicle technical control in everyday traffic

- Automatic traffic control and synchronization of traffic lights at some junctions

Introduction-timers at traffic lights that last longer than one min, especially at intersections with major significance,

- Planning and setting up of green shelterbelts and plantations of different scheduling multistory tree, shrub species, Linden, Berlin poplar, oak, hornbeam, Canadian poplar, birch and evergreen shrubs along the roads of traffic in order to reduce noise pollution.

\section{Conclusion}

The measuring cycle, noise pollution at the observed locations were significantly higher for the day, but for the night before all the sites, all located in a residential zone.

The noise in the middle of the utility derived from the observed counts of transport (public transport buses, heavy trucks, light vehicles) especially on the observed counts, which are actually the main traffic routes.
Measured values of noise pollution, exceeded especially at night, may adversely affect the relaxation and general health of the people in particular how their effects for continuous characters.

Noise problem that is increasingly present in the human living and working environment, achieves gradual culmination. It is sufficient to note that hearing loss by noise are present in the most visible problem occupational pathology. When we add the other, non auditory effects of noise on humans, it is clear what are the possible repercussions of pollution of our environment by noise. Do not forget to follow the noise and vibration, and ultrasound and infrasound who can not be heard, but they have a harmful effect on humans which is why this whole issue even more.

\section{Reference}

1. Preobraženski N.A.: Tugouhost, „Medicine"' Moskva 1978.

2. Schulltz T. J. Communiti Noise ratings, Applied Science Publishers, London 1972.

3. Simonović M., Kalić D., Pravica P.: Buka štetna dejstva merenje i zaštita, Niš 1982.

4. Simonović M.: Zvuk i vibracije, Buka, <<medicina rada, Sarajevo 1978.

5. Vaičić I.: Buka i njeno štetno dejstvo. Institut zaštite na radu, Niš

6. Yost W. A, Nielsen D. W.: Fundamentls of Hearing, Holt, Rinehart and Winston, New York 1979. 